\title{
DO NON-CLOSTRIDIAL ANAEROBIC BACTERIA CAUSE OF ACUTE PYELONEPHRITIS IN URETER OBSTRUCTION?
}

\author{
Pasechnik D. G. ${ }^{1}$, Kogan M. I. ${ }^{1}$, Mitusova E. V. ${ }^{2}$, Naboka Yu. L. ${ }^{1}$, Gazayev Z. I. ${ }^{3}$, \\ Ibishev Kh. S. ${ }^{1}$, Gudima I. A. ${ }^{1}$, Bejanyan S. K. ${ }^{1}$ \\ ${ }^{1}$ Rostov State Medical University, Russian Federation \\ 2 State Policlinic № 3, Rostov-on-Don, Russian Federation \\ 3 State Policlinic № 121, Moscow, Russian Federation

\section{ВЫЗЫВАЮТ АИ НЕКАОСТРИАИААЬНЫЕ АНАЭРОБНЫЕ БАКТЕРИИ ОСТРЫЙ ПИЕАОНЕФРИТ ПРИ МОЧЕТОЧНИКОВОЙ ОБСТРУКЦИИ?}

\author{
А. Г. Пасечник' ${ }^{1}$ М. И. Коган', Е. В. Митусова ${ }^{2}$, Ю. А. Набока', З. И. Газаев ${ }^{3}$, \\ Х. С. Ибишев ${ }^{1}$, И. А. ГУАима' ${ }^{1}$, С. К. БеАЖанян ${ }^{1}$ \\ 1 Ростовский госуАарственный МеАицинский Университет, Российская ФеАерация \\ 2 ГороАская поликАиника № 3, Ростов-на-Аону, Российская ФеАерация \\ 3 ГороАская поликАиника № 121, Москва, Российская ФеАерация
}

The problem of etiology and pathogenesis of acute obstructive pyelonephritis remains an outstanding issue in modern urology. The infectious nature of acute destructive renal processes presently remains disputed. Etiologic agents of pyelonephritis may be both gram-negative and gram-positive opportunistic bacteria, the majority of which is part of normal human microflora. Presently, several publications delegated that role to non-clostridial anaerobic microorganisms, found in tissue substrates in as much as $99.0 \%$ of cases. But their contribution to the etiology and pathogenesis of urinary tract infections is presently not sufficiently investigated. The experiment studies the morphologic specifics of acute obstructive pyelonephritis caused by various taxa of non-clostridia anaerobic bacteria. The data obtained changed the existing views on the detection and influence of said group of microorganisms upon the course of acute pyelonephritis in ureter obstruction.

Key words: acute obstructive pyelonephritis, non-clostridial anaerobic bacteria, urinary tract infection, morphological changes

Проблема этиологии и патогенеза острого обструктивного пиелонефрита остается одной из актуальных вопросов современной урологии. До настоящего времени дискутируются вопросы инфекционной природы возникновения острого деструктивного процесса в почке. Этиологическими агентами пиелонефрита могут быть как грамотрицательные, так и грамположительные условно-патогенные бактерии, большинство из которых принадлежат к нормальной микрофлоре человека. В настоящее время появляются исследования, в которых эта роль отводится неклостридиальным анаэробным микроорганизмам, частота обнаружения которых в тканевых субстратах может достигать 99,0 \%. Однако их удельный вес в этиологии и патогенезе инфекций мочевых путей в настоящий момент изучен недостаточно. В эксперименте были изучены морфологические особенности острого обструктивного пиелонефрита, вызванного различными таксонами неклостридиальных анаэробных бактерий. Полученные данные изменяют существующие воззрения на выявление и влияние данной группы микроорганизмов на течение острого пиелонефрита при мочеточниковой обструкции.

Ключевые слова: острый обструктивный пиелонефрит, неклостридиальные анаэробные бактерии, инфекция мочевыводящих путей, морфологические изменения

T he uropathogenes involved in the development of acute kidney diseases are mostly classified as belonging to family Enterobacteriaceae (E. coli, Klebsiella spp., Proteus spp. et al.) and a narrow pattern of gram-positive microflora (S. aureus, S. saprophyticus, Enterococcus spp.). The ability of those bacteria to cause both acute gematogenic pyelonephritis and acute kidney damage in ureter obstructions has been proven by multiple clinical and experimental research $[7,8,9$, $10,14]$. But are those microbial agents the only ones capable of causing acute pyelonephritis? Perhaps the scope of potential uropathogens is much broader? An answer to that question has been sought since long ago. Back in 1939 Schulte T. et al. [12] isolated form the urine of a patient with unilateral pyelonephritis associations of bacteroids and anaerobic streptococcus. Later, the "new" potential uropathogenes in adults and children were expanded to include some other taxa of nonclostridial anaerobic bacteria (Lactobacillus spp., Bifidobacterium spp. et al.) $[3,4,5,11]$. 
A number of recent researches of the urine microbiote and microbiome has shown that the urine of a healthy human or a patient with urinary tract infection (UTI) contains a broad scope (up to 45 genera) of anaerobic and anaerobic bacteria [13]. In this regard, isolation of non-clostridial anaerobic bacteria (NAB) from the urine of a relieved pelvis in ureter obstruction with bacteruiuria level of $\geq 10^{3} \mathrm{CFU} / \mathrm{ml}$ definitely raises a question of their possible involvement in the development of acute pyelonephritis. From the 8-10 representatives of NAB in such patients, most frequently found in urine are Peptococcus spp., Eubacterium spp., Bacteroides spp., Peptostreptococcus spp., and Propionibacterium spp. $[1,2]$. In was necessary to prove or rule out their capability to reproduce under the conditions of ureter obstruction in experimental acute pyelonephritis.

The aim of the study was to research the morphologic specifics of experimental acute obstructive pyelonephritis caused by various taxa of non-clostridial anaerobic bacteria.

Material and Methods. The experimental model of acute obstructive pyelonephritis (AOP) was reproduced following the method of Giamarellors-Bourbalis E. et. al (2004) [6]. Male New Zealand breed rabbits used in the experiment were aged 3.5 months and of $3.11 \pm 0.69 \mathrm{~kg}$ weight, distributed into 7 groups of 10 animals in each: I group - hydronephrosis model, II group - AOP caused by E. coli, III group - by Peptococcus spp., IV group by Eubacterium spp., V group - by Propionibacterinum spp., VI group - by Bacteroides spp. and in the VII group - a mix of E.coli and Peptococcus spp. The cultures of microorganisms for the experiment were obtained from AOP patients in the first day of disease (before commencing antibacterial therapy). Choice of the specified bacterial genera was based on the fact that $E$.coli is a generally proven pathogen in AOP, while Peptococcus spp., Propionibacterinum spp., Eubacterium spp. and Bacteroides spp. are most frequently detected in the urine of AOP patients.

The animal welfare, nourishment, care and euthanasia were performed in accordance with the requirements of the «Helsinki declaration» of 2000 и «Directive 2010/63/ EU of the European parliament on the European Union council on the protection of animals used for scientific purposes» (2010). The research received approval of the Ethics committee of GBOU VPO RostGMU Russian Federation Ministry of Health (№ 20/12 of 20.12.2012). All animals were kept in original conditions: temperature $\left(20-23^{\circ} \mathrm{C}\right.$ ), humidity, illumination (with $12 / 12$ hourly cycle of light/darkness), as well as the nutrition ration. The rabbits had free access to food and water and were left to adapt to the environment for a week before the experiment. The animals were initially sedated by intramuscular zoletil solution $(15 \mathrm{mg} / \mathrm{kg})$, then intravenously, through the marginal ear vein, injected $1 \%$ water emulsion of propofol $(5.0-7.5 \mathrm{mg} / \mathrm{kg})$. The abdominal cavity was opened by an upper-medial abdominal section $4.0 \mathrm{~cm}$ long. The intestines were displaced to the right. After visualization, the left ureter was surrounded by a 3/0 vicryl thread in a position $2.5 \mathrm{~cm}$ distal from the renal pelvis, and pulled to the front abdominal wall. Both ends of the thread were passed through the front abdominal wall to the outside and tied on the skin. Bacterial pathogens in a concentration of $10^{5} \mathrm{CFU}$ in $1.0 \mathrm{ml}$ of saline were injected through a $26 \mathrm{G}$ needle into the renal pelvis. The front abdominal wall was sutured by layers.

For infecting the animals, a one-day suspension of E. coli, cultured on meat infusion agar, and 48 hour cultures of Peptococcus spp., Propionibacterinum spp., Eubacterium spp. and Bacteroides spp., cultured on Schaedler Agar were used. The researched cultures were washed off with saline and standardized using an optical standard. After induction into the experiment, the animals were kept in the same conditions. The animals were euthanized on the $1,3,7,14$ and 21 day. Animals of group VII survived to 12-14 days only. The autopsies were performed aseptically, in an operating room. For performing histological research, fragments of kidneys and other organs were extracted, fixated in neutral $10 \%$ formalin solution with subsequent hematoxylin-eosin staining and slide preparation, as well as photography using a Leica DND 180 microscope.

Results. It has been established that in group I animals within 1-3 day of the experiment there arose moderate pelvis ectasis, widening of the excretory and collecting ducts of the medulla and cortex. On the 7th day pyelocaliectasis increases. In the cortex and medulla evident ectasis of tubules and ducts, venous congestion and stasis in the cortex, small foci of papillonecrosis are found (Fig. 1). By day 14-21 obstruction signs increase, with evident ectasis of the tubule and duct system, with localized microcyst transformation combined with epithelial atrophy, foci of epithelial-mesenchimal transition and interstitial fibrosis. Thus, by the 3rd week the kidney demonstrates a typical morphological picture of hydronephrosis.

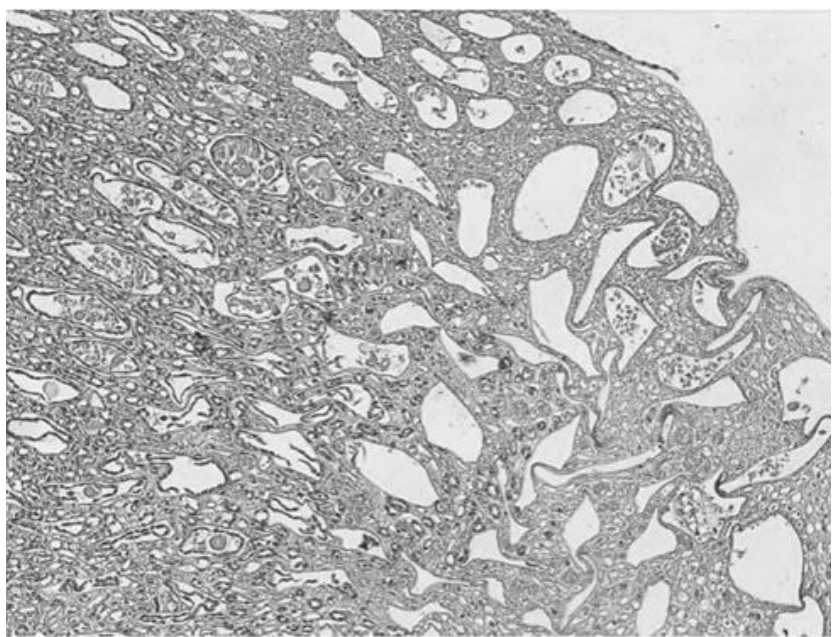

Fig. 1. Expressed ectasis of renal pyramid excretory ducts. Small papillonecrosis foci (7th day of obstruction). Hematoxylin-eosin stain, magnification x200

In the II group animals (E. coli) during the first day of experiment, in the pelvis and renal sinus parenchyma there is observed diffuse suppurative inflammation and acute septic phlebitis. In the kidney, in the presence of duct ectasis, there is observed neutrophil accumulation in their clearance, moderate interstitial edema. By the 3-7th day in the renal sinus parenchyma and paranephrium, in the pelvic wall there persist signs of suppurative inflammation. The development of suppurative tubulitis, foci of papillonecrosis, acute abscesses and infarctions involving the cortex and medulla is defined (Fig. 2). By day 14-21 the renal sinus parenchyma, paranephric fat, renal parenchyma the foci of necrosis and suppurative inflammation are combined with the development of granulation and scar tissue. Further duration demonstrates in the kidney signs of expressed obstruction - intermingled foci of tubule and duct atrophy, collapsed glomeruli, expressed interstitial fibrosis with localized lympho-hystio-plasmocyte infiltration, with foci of sharply ectatic ducts and tubules, with local microcystic structures. 


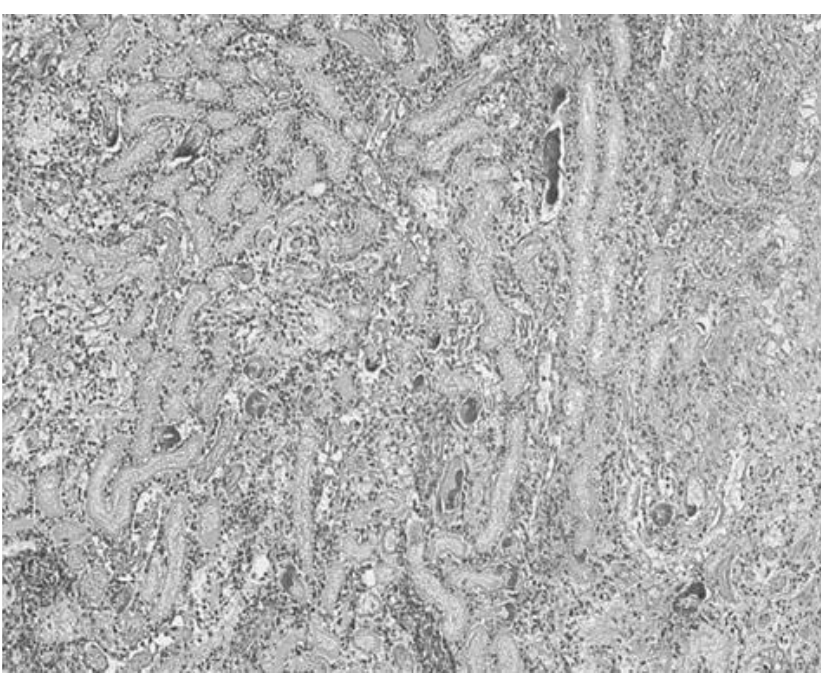

Fig. 2. Renal infarction and aggregation of microbes in the clearance of collecting ducts. Third day after infecting with E. coli. Hematoxylin-eosin stain, magnification x200

In the III group animals (Peptococcus spp.) the morphologic presentation is largely similar with group II. At days 1-3 the most expressed changes are observed in the renal sinus area. By day 3 the inflammation extends to the paranephric parenchyma. In the renal pyramid, in the areas adjacent to calices, there develop foci of papillonecrosis and suppurative inflammation with focal infarctions of the renal parenchyma. At day 7 in the renal sinuses, paranephrion, pelvic wall and renal parenchyma there persists an expressive suppurative inflammation with pus accumulation in the renal pelvis, abscesses and papillonecrotic foci. Simultaneously with suppurative inflammation there is registered development of a granulating tissue rich in miofibroblasts and myxomatosis, lympho-hystio-plasmocyte infiltrates and coarse-fiber conjunctive tissue. By day 21 the suppurative inflammation foci decrease in size and quantity, scar tissue begins replacing them. In the kidney tissues changes there prevail changes related to obstruction of the urinary tract and development of hydronephrosis.

In the IV group animals (Eubacterium spp.) the dynamics and character of morphological changes are similar to animals of groups II and III. The specific aspect of kidney and adjacent tissue damage in this group is rapid spreading of infection through the tubule-duct system already on the first day from infection, expressed destructive changes in the kidney tissue. A large amount of microbes in the necrotic foci persists on the following days as well.

In the $\mathrm{V}$ group animals (Propionibacterinum spp.) unlike groups II-IV the inflammatory reaction develops as an acute exudative serosal and serosal-fibrinosal inflammation in the renal pelvis wall and adjacent sinus parenchyma only in the first three days from the moment of infection. The principal morphologic changes observed in the kidney and renal pelvis later correspond to progressing obstructive nephropathy.

In the VI group animals (Bacteroides spp.) the dynamics and character of morphological changes match the II-IV experimental groups.

In the VII group animals (E. coli + Peptococcus spp.) on day 1 there is observed an expressed venous congestion involving both the renal sinus and the renal parenchyma. In the renal sinus parenchyma, the renal pelvis, the cortex excretory and collecting ducts a high quantity of microbes, focal suppurative inflammation, predominantly around veins, with development of suppurative septic thrombophlebitis (Fig. 3). By day 3 in the kidney, renal pelvis wall and paranephrion hemorrhagic necrosis foci with a high quantity of microbes are formed. By day 7 the purulonecrotic changes in the renal pelvis wall, parenchyma and kidney tissue mount up. At days 14 foci of suppurative inflammation are combined with foci of granulating and coarse fibrous scar tissue formation, signs of expressed obstructive nephropathy, in the kidney interstitial lympho-hystio-plasmocyte infiltration prevails.

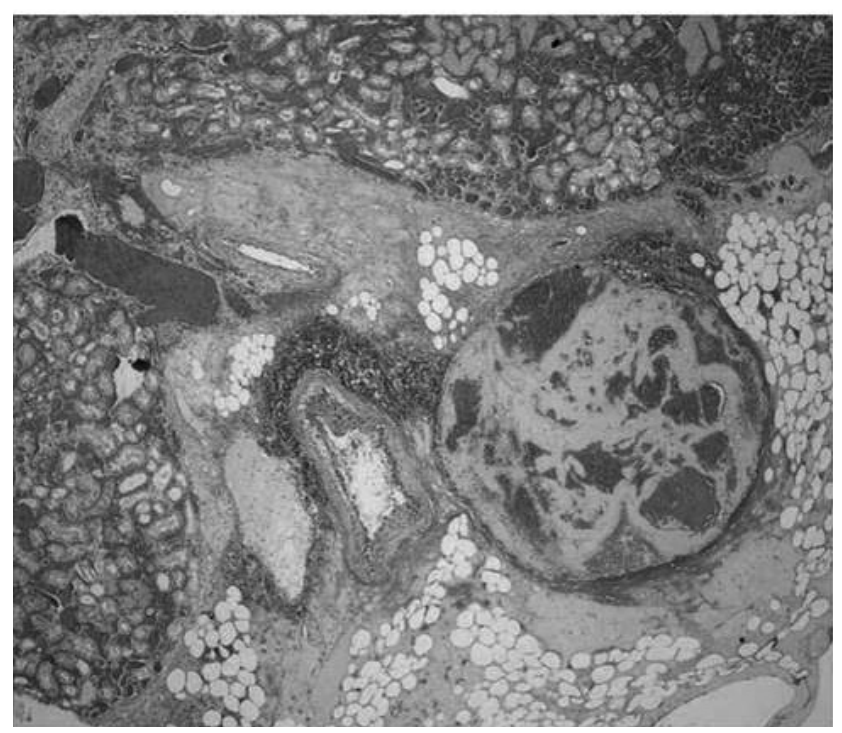

Fig. 3. Intense congestion and hemorrhage in renal tissues. Acute suppurative trombovasculitis in the renal sinus (1st day after microbial mixture infection). Hematoxylin-eosin stain, magnification $\times 100$

Conclusions. The research has determined that anaerobic microorganisms in the experimental ureter obstruction model cause acute pyelonephritis when inoculated in the renal pelvis. The character of morphological changes and their dynamics are similar to the classic development of pyelonephritis caused by $\mathrm{E}$. coli. During the first day since infection the inflammation mostly involves the parenchyma and vessels of the renal sinus, partially spreading to the renal pelvis wall. The renal tissue displays only ectasis of tubules and ducts, dystrophic changes of tubule epithelium, venous congestion of the cortex. By day 3-7 in the renal pelvis, surrounding parenchyma and kidney purulonecrotic changes mount up, with formation of acute abscesses, infarctions, papillonecrotic foci. Following day 7 around necrosis and inflammation foci in both parenchyma and kidney tissue the emergence of granulating tissue is detected, which by day 14-21 transforms into coarse-fibre oligocellular scar tissue. In the inflammatory infiltrate of the interstitium lymphocytes, plasmatic cells and macrophages prevail. The inflammatory changes are combined with changes related to urinary duct obstruction a progressing atrophy of tubule and duct epithelium, interstitial fibrosis. The difference in kidney damage presentation when infected with different agents are related to the depth and extent of purulonecrotic changes. For the mixed infection, a potentiating effect of microorganisms is characteristic, with especially destructive changes in the kidney and intense microbe propagation. 
References

1. Naboka Y. L., Kogan M. I., Gudima I. A., Chernickaja M. L., Ibishev Kh. S. Role of non-clostridial anaerobes in the development of infectious and inflammatory diseases of the urinary and reproductive systems. Urology. 2013;4:16-18.

2. Kogan M. I., Naboka Y. L., Gudima I. A., Gazaev Z. I., Ibishev Kh. S. et al. New view on etiological structure of the acute obstructive pyelonephritis. Contemporary problems of science and formation. 2012;4. www. science-education.ru.

3. Apostolopoulou C., Konstantoulaki S., Androulakakis P. Vatopoulou T., Varkarakis M. Isolation of anaerobic organisms from kidney in serious renal infections. Urology. 1982;20(5):479-481.

4. Brook I. Urinary tract infection caused by anaerobic bacteria in children. Urology. 1980;16(6):596-598.

5. DuPrey K. M., McCrea L., Rabinowitch B. L., Azad K. N. Pyelonephritis and Bacteremia from Lactobacillus delbrueckii. Case Rep. Infect. Dis. 2012;10:1155-1158.

6. Giamarellos-Bourboulis E., Adamis T., Laoutaris G., Sabracos L., Koussoulas V. Immunomodulatory clarithromycin treatment of experimental sepsis and acute pyelonephritis caused by multidrug-resistant Pseudomonas aeruginosa. Antimicrobial Agents and Chemotherapy. 2004;48(1):93-99.

About authors:

Pasechnik Dmitry, MD, Head of Central scientific research laboratory; tel.: +792888428-41; e-mail: passetchnikdg@hotmail.com

Kogan Mikhail, MD, PhD, Professor, Head of Department of urology and human reproductive health with child urology

andrology course of the FPK and PPS; tel.: +79282260126; e-mail: dept_kogan@mail.ru

Naboka Yulia, MD, PhD, Professor of Department of microbiology and virusology № 1; tel.: +79289074013; e-mail: nagu22@mail.ru

Ibishev Khalid, MD, PhD, Professor, Head of Department of urology and human reproductive health with child urology

andrology course of the FPK and PPS; tel.: +79287777714; e-mail: ibishev22@mail.ru

Bejanyan Saro, postgraduate at Department of urology and human reproductive health with child urology

andrology course of the FPK and PPS; tel.: +79508444882; e-mail: sarik2802@yandex.ru

(C) Group of authors, 2016

UDC 616.716.8.002.69:352.41/16.32.09

DOI - http://dx.doi.org/10.14300/mnnc.2016.11039

ISSN - 2073-8137

\title{
PATHOMORPHOLOGICAL CHANGES OF DENTAL PULP IN EXPERIMENTAL OSTEOPOROSIS
}

Sirak S. V. ', Shchetinin E. V. ', Sirak A. G. ${ }^{1}$, Koshel I. V. ${ }^{1}$, Kobylkina T. L. ${ }^{1}$, Aybazov M. M. ${ }^{2}$, Vafiadi M. Yu. ${ }^{1}$, Adamchik A. A. ${ }^{3}$, Mamontova T. V. ${ }^{2}$

' Stavropol State Medical University, Russian Federation

${ }^{2}$ All-Russian Research Institute of Sheep and Goat Breeding, Stavropol, Russian Federation

${ }^{3}$ Kuban State Medical University, Krasnodar, Russian Federation

\section{ПАТОМОРФОАОГИЧЕСКИЕ ИЗМЕНЕНИЯ ПУАЬПЫ ЗУБОВ ПРИ ЭКСПЕРИМЕНТААЬНОМ ОСТЕОПОРОЗЕ}

\author{
С. В. Сирак', Е. В. Щетинин', А. Г. Сирак', И. В. Кошель', Т. А. Кобылкина', \\ М. М. Айбазов ${ }^{2}$ М. Ю. Вафиали', А. А. ААамчик ${ }^{3}$, Т. В. Мамонтова ${ }^{2}$
}

\footnotetext{
' Ставропольский госуаарственный меАицинский университет, Российская ФеАерация

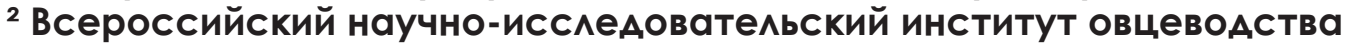
И козовоАСтва РАН, Ставрополь, РосСиЙская ФеАерация

${ }^{3}$ Кубанский госУАарственный МеАицинский Университет, КрасноАар, Российская ФеАерация
}

The study focused on pathomorphological changes taking place in the tooth pulp in sheep in case of experimental osteoporosis. The pulp was extracted after cracking the teeth. The sections were stained with hematoxylin and eosin by Masson, and impregnated with silver by Foot and Bielschowsky-Gros. There were severe vascular disturbances 